\title{
STEEL CONSTRUCTION OF MODERN BUILDING OF FORMER SPORTS HALL AT CHOPIN STREET IN ZIELONA GÓRA
}

\author{
Bartosz MICHALAK ${ }^{1}$ \\ University of Zielona Gora, Zielona Góra, Poland
}

\begin{abstract}
Modernism in architecture of the lubuskie voivodeship is not dominating style . Objects created in the period of its greatest popularity are still fighting for recognition of their value as historical monuments. One of such facilities in Zielona Góra is building at Chopin street, where today is The Teacher Training Centre. However, originally object was intended to be a sports hall. The topic worth of further analysis is the construction of the building. The skeleton is a unique steel frame, made in 1930 by the famous pre-war company Fabrik und für Brückenbau Eisenkonstruktionen BEUCHELT \& Co. Grünberg in Schlesien. In order to build walls the brick technology was used. It is a rarely seen combination that indicates the attempt to experiment with new solutions by engineers of the era of modernism.
\end{abstract}

Keywords: modernism, steel structure, Beuchelt, sports hall

\section{INTRODUCTION}

Architecture of modernism in Zielona Góra is not a dominating style. The buildings that were built in the days of its splendor are considered valuable in the program of protection of monuments only by a small group of specialists. Due to this adverse point of view, a lot of valuable objects are deteriorating, or undergoing makeovers that are completely losing the original architectural

\footnotetext{
${ }^{1}$ Corresponding author: University of Zielona Gora, Faculty of Civil Engineering, Architectureand Environmental Engineering, Z. Szafrana st 1, 65-516 Zielona Góra, Poland, e-mail: b.michalak@ib.uz.zgora.pl, tel. +48683287343
} 
values, or worse, these buildings are demolished. One of the most interesting examples of the local modernism is the building of the former sports hall at Chopin street (Ger. Lindenberg) in Zielona Góra. Fortunately, this particular building was listed as a historic building, protected by law in 2012 .

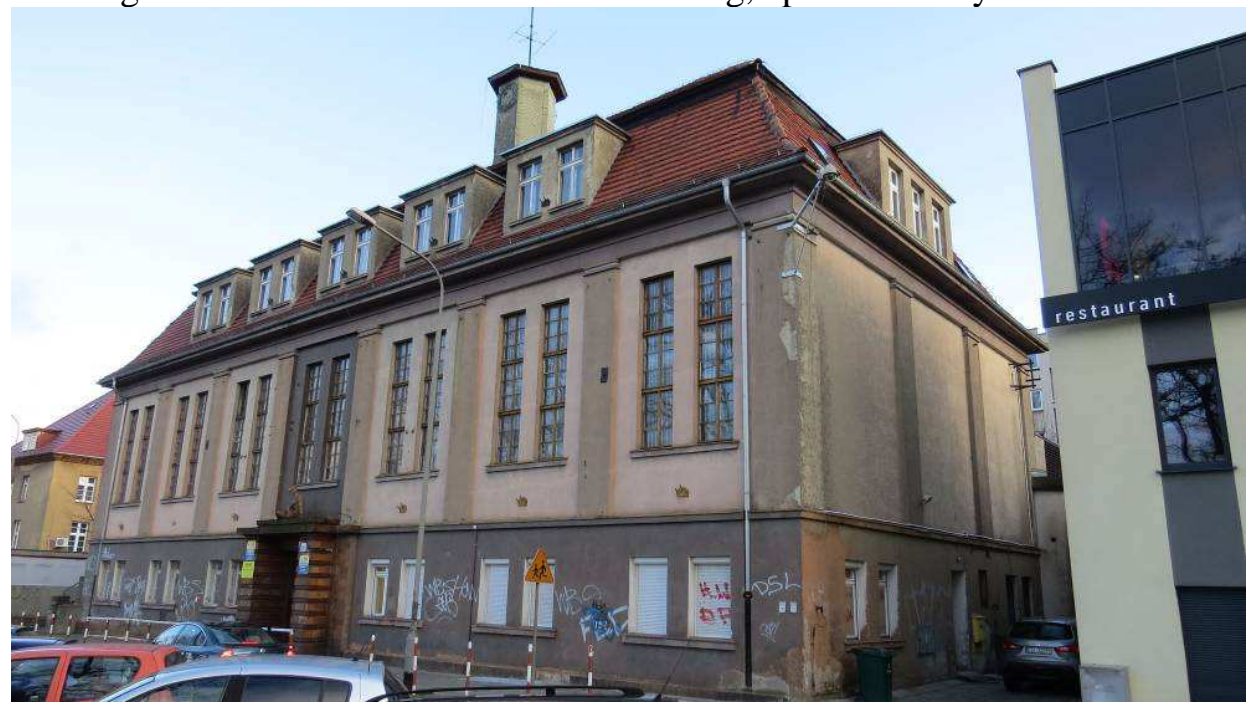

Fig. 1. The front elevation (2015)

\section{HISTORY OF THE BUILDING}

The sports hall was built and opened in 1930, and the investor was the City Building Office in Zielona Góra (Stadtbauamt Grünberg in Schlesien). The architectural design was created in 1928, whereas the structures were designed in 1929 by Zielona Góra well-known plant Fabrik für Brückenbau und Eisenkonstruktionen Beuchelt \& Co. Grünberg in Schlesien (Department of bridges construction and iron structures Beuchelt \& Co. Zielona Góra in Silesia). The factory founded by Georg Beuchelt also looked into the performance of the steel structure of the hall. After the war, it was the biggest sports center in Zielona Góra, there were played the first basketball match of Zastal. Today it is owned by the The Teacher Training Centre.

\section{ARCHITECTURE OF THE BUILDING}

The building was designed on a rectangular plan with dimensions of $34.00 \mathrm{x}$ $16.00 \mathrm{~m}$. From the south-east side one distinguished a rectangular tower of dimensions $5.40 \times 6.30 \mathrm{~m}$, housing the staircase in a three-running return 
system between the ground and first floor, among other storeys in a two-running system. The property has four floors, basement and topped with a mansard roof with dormers. At the top of the roof is placed a clock tower of a hexagonal section. The ground floor of the building with a height of 3.30 meters is fully designed for office rooms, arranged symmetrically with respect to a centrally placed staircase. The first floor with a height of $7.00 \mathrm{~m}$ is fully occupied by a gym with changing rooms. In the upper part there is a small observation gallery. The last floor with a height of $4.20 \mathrm{~m}$, which is the attic, originally was intended for storage space, now there are office spaces.

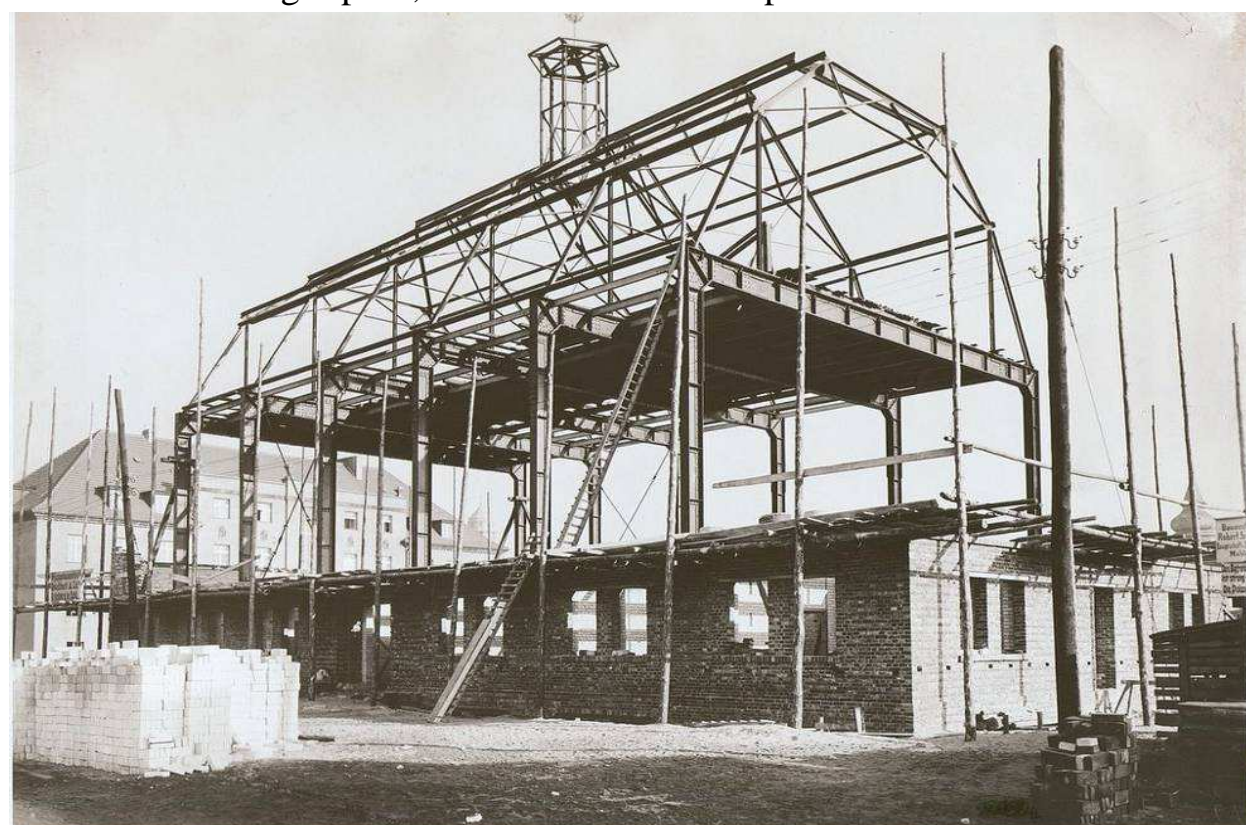

Fig. 2. The frame of the building (1930)

Basement in total was intended for technical functions, including the boiler room. Despite minor changes inside, the building still retained its original, modernist look, form and layout of the rooms. Many elements such as windows and doors woodwork, sculpture of an athlete resting on the ball, which adorns the main entrance or the pre-war crest of Zielona Gora also remained intact.

\section{CONSTRUCTION OF THE BUILDING}

The building construction has an oblong arrangement, is made of steel, is wireframed with six repetitive steel frames. Frames were made of steel H-beams I450, stiffened by transverse ribs. Connections of the elements were 
implemented by means of rivets. Columns are clamped with screws and anchors of a diameter $25 \mathrm{~mm}$ in the wall with a thickness of $0.51 \mathrm{~m}$ on the ground level in concrete flooded holes with a section of $0.25 \times 0.08 \mathrm{~m}$. The depth of the restraint bolt is $1.00 \mathrm{~m}$. From the staircase in the wall in the oblong direction one installed a set of two steel H-beams, serving as additional support for the stairs. The construction of floors above the ground floor is based on the binders made of H-beams I240, fastened with screws to the main frame columns, in their anchorage in the wall. Over the first floor (the gym) were used a classic Klein ceiling, which also acts as oblong stiffener.

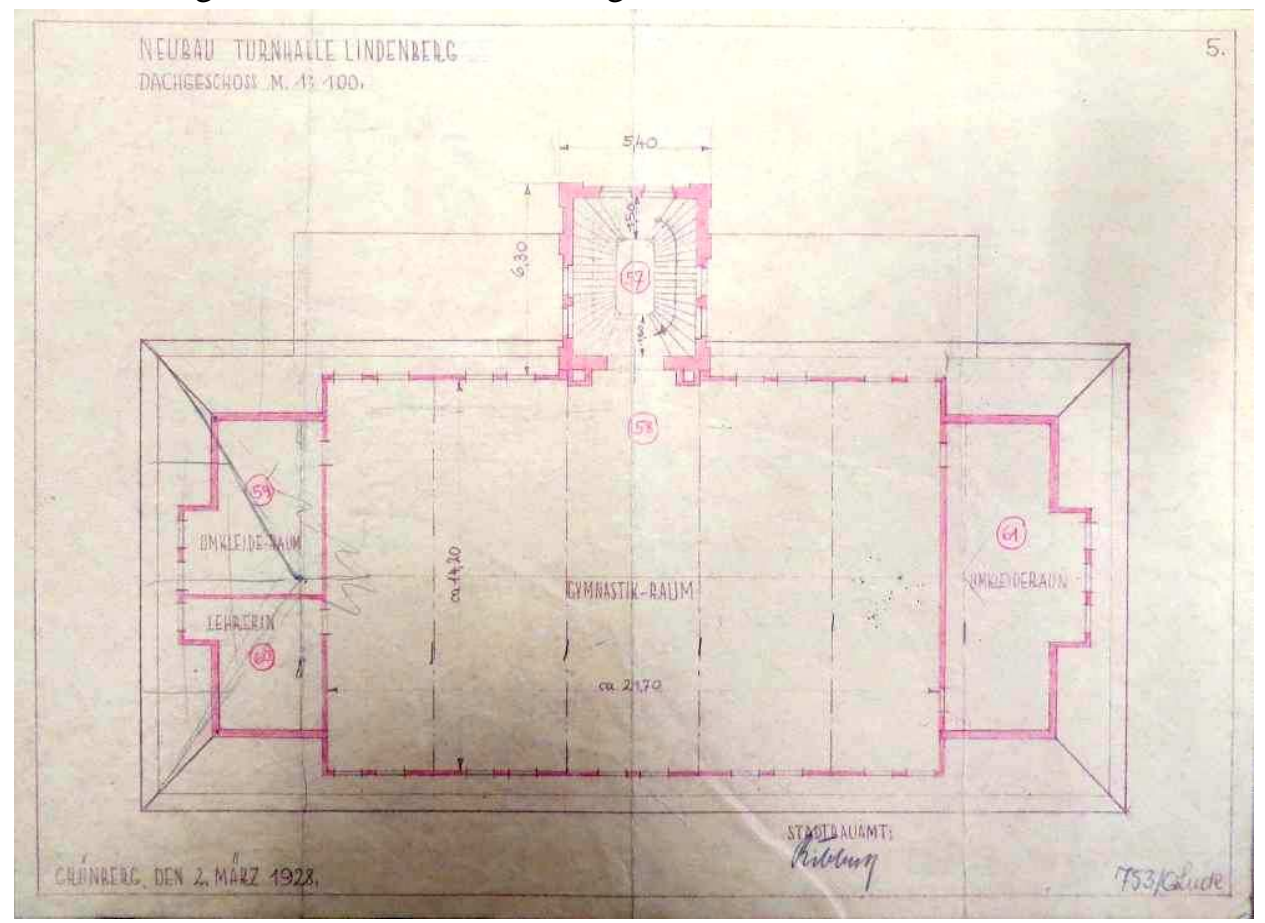

Fig. 3. Floor section with the gym (1928)

A wall construction on other floors only acts as a curtain wall. The whole is based on the concrete foundation strips with a width of $1.20 \mathrm{~m}$, situated on the depth of $2.80 \mathrm{I} 3.90 \mathrm{~m}$, respectively from the north-west and south-east side. Rafter is also made of steel. The trusses are reproducible and based on the previously described steel frames, creating a mansard roof system. The construction of a single truss is a steel girder made of steel H-beams with a height of $50 \mathrm{~mm}$ and $90 \mathrm{~mm}$, joined in nodes using rivets and the gusset plates. The role of the ridge and patches play steel H-beams. Between trusses 2, 3 and 
4 and 5 one used a wind machine. The role of stiffening between trusses 3 and 4 plays steel construction of the clock tower.

The above-described design solutions are not typical and indicate that the engineers of modern era tried to experiment with relatively new, at the time, materials such as steel and concrete, combining them with well-known wall structures. The basic motto of the architects of that period was "form follows function".

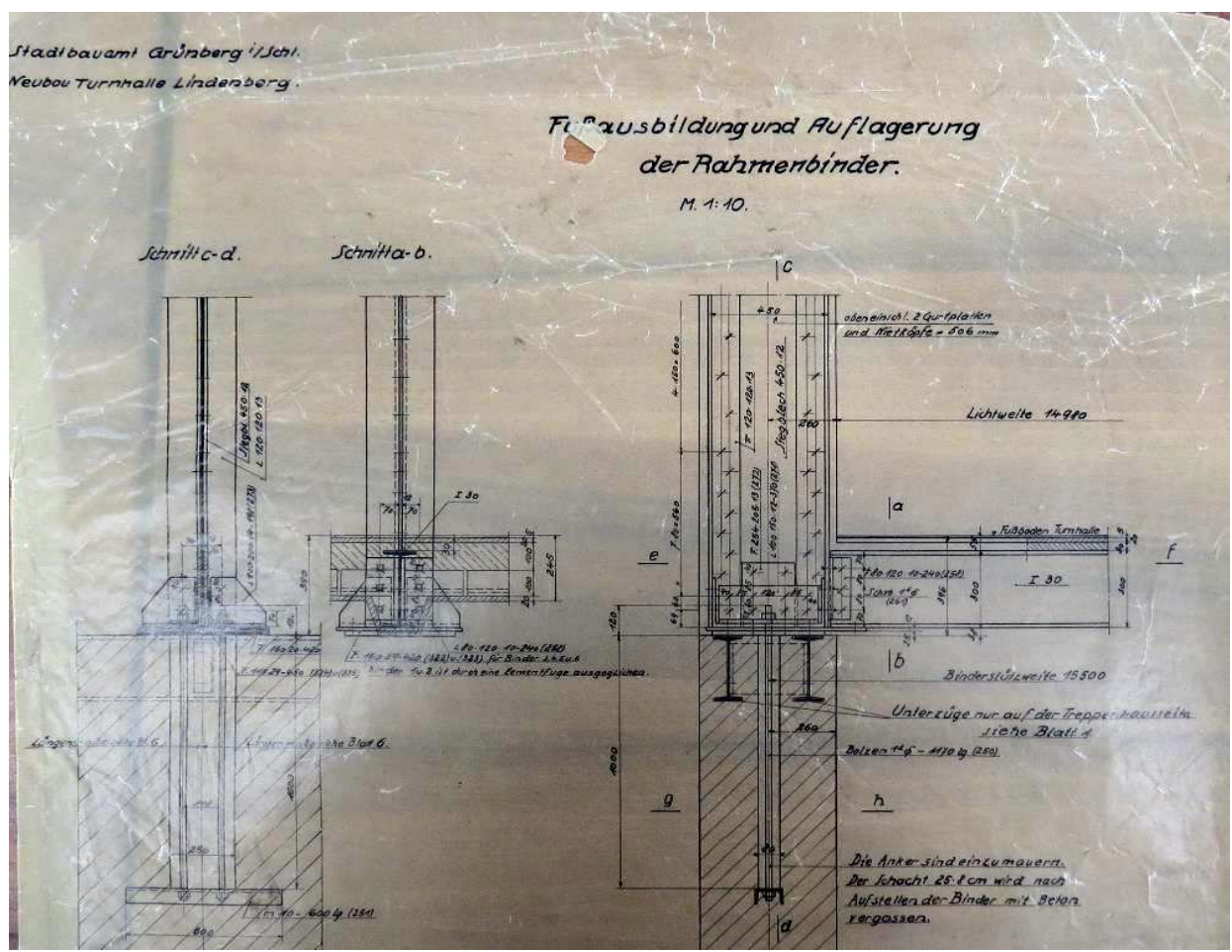

Fig. 4. The method of anchoring pillars in the wall (1929)

The sports hall being the subject of this article is the proof that it was true. The primary objective of such facility was to ensure undisturbed space for doing sports, the necessary additional rooms such as locker rooms, sports equipment stores and offices, all on a limited area of the building. The realization of this goal required to place the hall of significant dimensions, loaded with the crowd on the first floor of the building. The solution to this problem, using steel frames with a significant spread, today seems obvious, but combining it with anchoring them in a brick wall in concrete filled shafts, instead of directly in the foundation, and the use of steel truss in mansard roof, like at the turn of the $20 \mathrm{~s}$ and 30 s of the last century was unusual and innovative solution. When it comes 
to architectural form, the building fully corresponds to the assumptions of modernists. Devoid of unnecessary decoration, a simple rectangular block is richly glazed, spatial layout is simple and logical. Even staircase with a threerunning system acts as a representative only between the ground and the first floors.

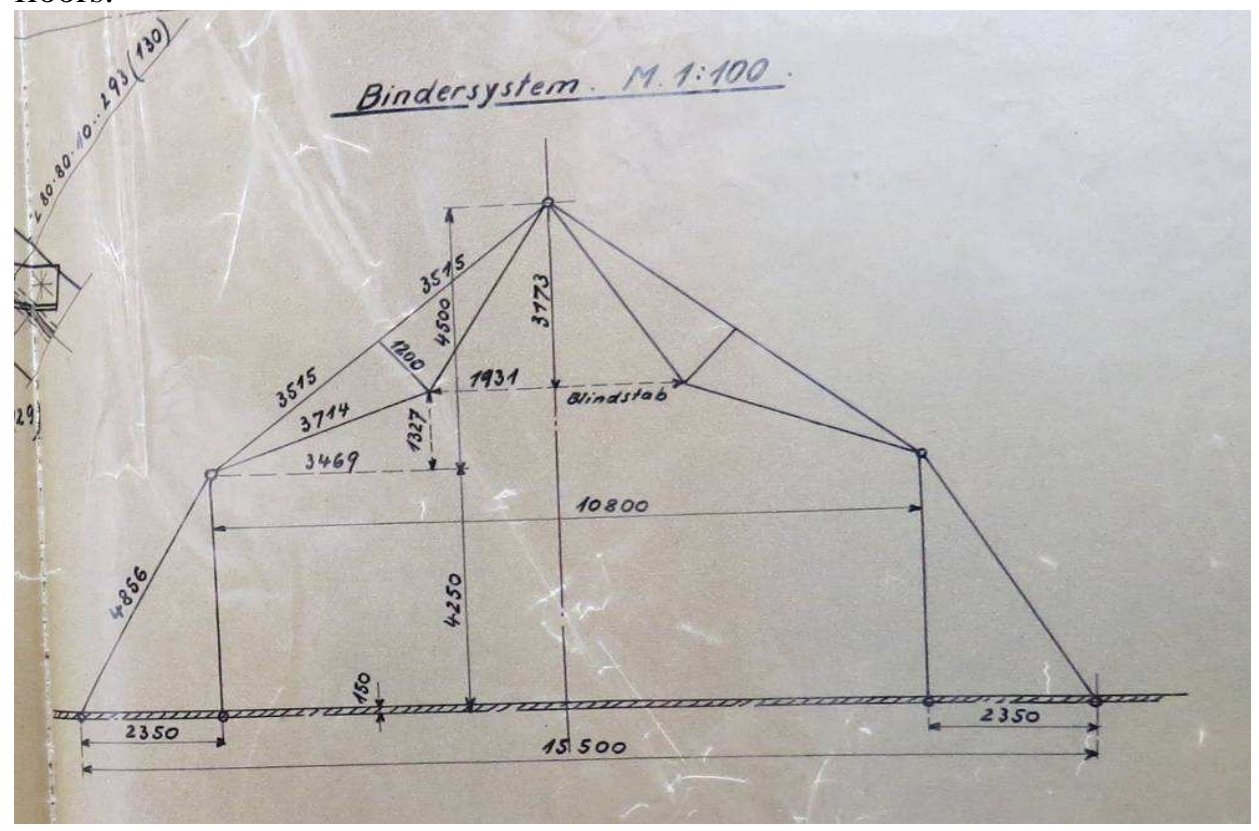

Fig. 5. Plan of steel roof truss (1929)

\section{CONCLUSIONS}

This building was registered as a monument and, because of it, we can be sure that it faces no longer uncontrolled reconstruction or demolition. However, one should be aware that in the area of Lubuskie voivodship there are still many buildings from the modernism times that are unexplored and are still fighting for recognition of their value as monuments. Unfortunately there are no proper evaluation, documentation and depreciating their importance has led in recent decades to changing the appearance, function and construction of many of them. But it is worth the trouble to get to know them, in order to make the institutions responsible for the protection of monuments and the wider cultural heritage receive the basis to care for them. 


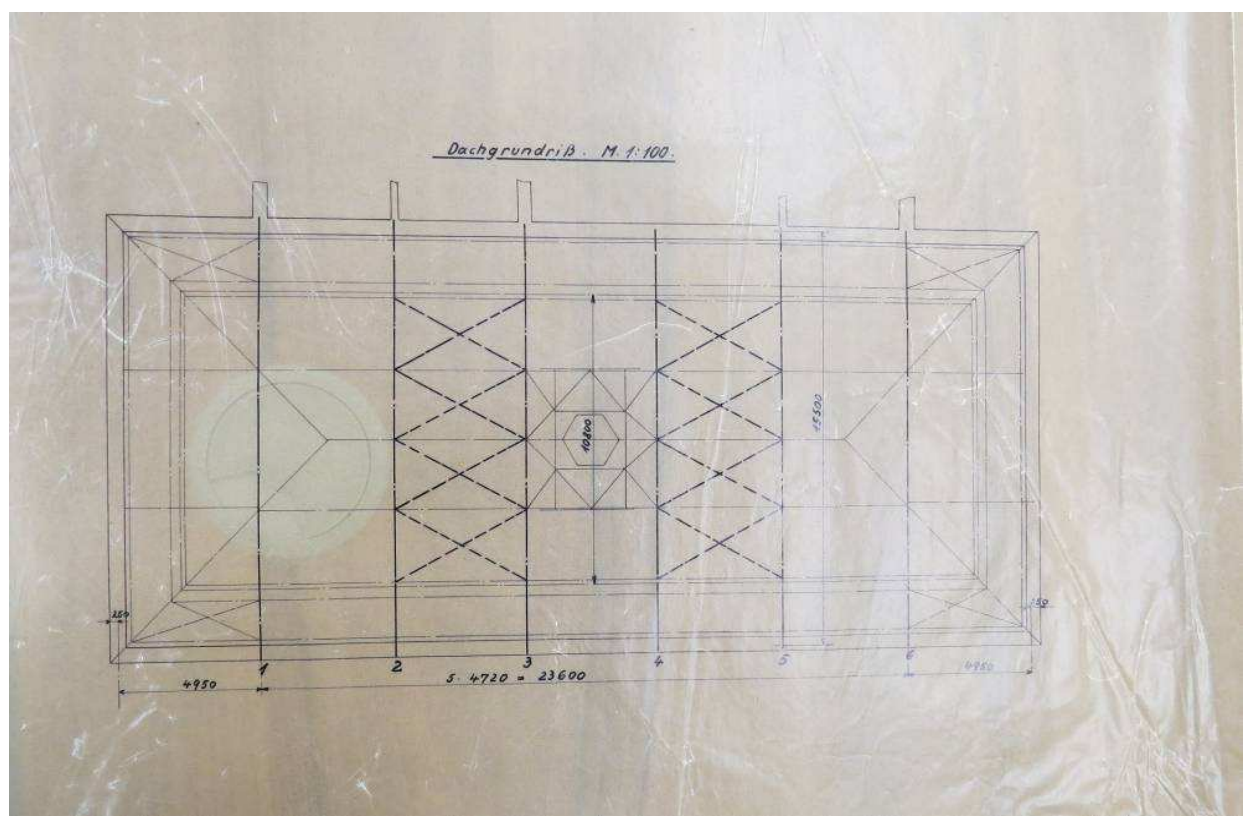

Fig. 6. Plan of roof truss girders with wind machines (1929)

\section{REFERENCES}

1. Tokarz B. Perty, których zazdrości nam Europa. Rozmowa z Barbarq Bielinis-Kopeć. Wyborcza.pl, 11/2012, str. 1-13

2. Oryginalna dokumentacja projektowa firmy Beuchelt\&Co., 1928-1929, Archiwum Państwowe w Zielonej Górze

\section{KONSTRUKCJA STALOWA MODERNISTYCZNEGO BUDYNKU DAWNEJ HALI SPORTOWEJ PRZY UL. CHOPINA W ZIELONEJ GÓRZE}

\section{Streszczenie}

Modernizm w architekturze województwa lubuskiego nie jest stylem dominującym. Obiekty powstałe w okresie jego największej popularności wciąż walczą o uznanie ich wartości jako zabytków. Niestety brak właściwej oceny, dokumentacji oraz deprecjonowanie ich znaczenia doprowadziło w ciągu ostatnich dziesięcioleci do zmian wyglądu, funkcji oraz konstrukcji wielu z nich. Wciąż jednak istnieją przykłady budownictwa modernistycznego, których stan techniczny oraz charakter pozwalają na dokładne ich zbadanie oraz skatalogowanie, aby instytucje odpowiedzialne za ochronę 
zabytków i szeroko pojętego dziedzictwa kulturowego otrzymały podstawę do opieki nad nimi. Jednym z takich obiektów na terenie Zielonej Góry jest budynek przy ul. Chopina, w którym siedzibę dziś ma Ośrodek Doskonalenia Nauczycieli. Pierwotnie obiekt przeznaczony był jednak na halę sportową. Wiele elementów jak stolarka okienna i drzwiowa, rzeźba sportowca opierającego się na piłce, która zdobi główne wejście lub przedwojenny herb Zielonej Góry również pozostały nienaruszone. Po wojnie była to największa hala sportowa w mieście. Tematem wartym dalszej analizy jest konstrukcja budynku. Szkielet stanowi unikalna rama stalowa, wykonana w roku 1930 przez znaną przedwojenną firmę Fabrik für Brückenbau und Eisenkonstruktionen Beuchelt \& Co. Grünberg in Schlesien. Do budowy ścian wykorzystano klasyczną technologię murowaną. Jest to nieczęsto spotykane połączenie, które wskazuje na próby eksperymentowania z nowymi rozwiązaniami przez inżynierów z epoki modernizmu.

Słowa kluczowe: modernizm, hala sportowa, Beuchelt, konstrukcja stalowa.

Editor received the manuscript: 25.01.2015 